Journal of Extension Education

Vol. 28 No. 3, 2016

DOI:https: / / doi.org/10.26725/JEE.2016.3.28.5695-5702

\title{
A Quantitative Study on Indigenous Medicinal Plants used by Tribes of Kerala
}

\author{
Simi Asharaf ${ }^{1}$ and M. Sundaramari ${ }^{2}$
}

\begin{abstract}
A quantitative study of indigenous medicinal plants with detailed documentation among tribal people was carried out in Idukki Wildlife Sanctuary, Idukki District, Kerala State. Nine tribal settlements were selected for the study based on the area and availability of information. Accordingly 120 informants were selected purposively. Direct observation, semi structured interview and group discussion were used to collect the data from the informants. The collected data was analysed using Micro-soft Excel spreadsheet 2010 and summarized using descriptive statistical methods. Five different quantitative statistical tools such as Relative Frequency of Citation (RFC), Use value (UV), Relative Importance Index (RI), Relative Importance Index (RI), Fidelity Level (FL) and Informants' Consensus Factor (ICF) were analysed with score. Acacia caesia (L.) Wild had the highest RFC with rank I,; Adhatoda beddomei C.B. Clarke gave the highest use value with the maximum number of medicinal purposes (four).

A majority of species were found to be most used among the community. The highest level of ICF was obtained for urological ailments (UA) followed by gynaecological ailments (GAA) and Dermatological ailments (DA) in that order.
\end{abstract}

Keywords : Indigenous Medicinal Plants, Quantitative factors, Idukki district, Kerala

\section{INTRODUCTION}

Indigenous knowledge is the knowledge, innovations and practices of indigenous and local communities practiced around the world. Developed from experience, gained and tested over centuries and adapted to the local culture and environment, such knowledge is transmitted orally from generation to generation (Pushpangadan et al.,
2002). Indigenous medicine is a special type of indigenous knowledge with the integration of information, practices, technologies, beliefs, experimentation, biological resources, human resources and communication. In developing countries, many people (more than $80 \%$ ) depend on indigenous medicines because they have no access to modern medicines and accepted as it is safe (Runyoro et al., 2006). Traditional healers act as

1. Ph.D.Scholar, Faculty of Agriculture and Animal Husbandry, Gandhigram Rural Institute- Deemed University, Gandhigram-624 302 and 2. Professor (Agricultural Extension), Faculty of Agriculture and Animal Husbandry, Gandhigram Rural Institute-Deemed University, Gandhigram-624 302

Received : 15-05-2017; Accepted : 15-06-2017 
a core of the community, taking more advantages over diverse species of flora and fauna and they are carrying it to next generation. Indigenous medicinal inventories are today recognized as the most effective method of identifying new medicinal plants or refocusing on those plants reported in earlier studies for the possible extraction of beneficial bioactive compounds (Thirumalai et al., 200).

The present study was designed to document the medicinal uses of plants and to determine Relative Frequency Index (RFC), Use Value (UV), Relative Importance (RI), Fidelity Level (FL) and Informants' Consensus Factor (ICF) of such species/ ailments of Kannampadi, part of Idukki Wild Life Sanctuary, in order to evaluate their potential for new drugs of herbal origin.

\section{METHODOLOGY}

\section{Study Area and Selection of Respondents}

The study was undertaken during 2015-2016, in remote tribal settlements located inside the Idukki Wildlife Sanctuary, Idukki in Kerala, India. It is the natural abode of the aboriginal tribes - such as Malayarayans and Uralis whose main occupation is agriculture. Nine tribal settlements namely Memari, Kannampadi, Kathitheppan, Thekkuthottam, Vakkathi, Kollathikkadu, Keezhukaanam, Mullam and Punnappara were selected after consulting with Integrated Tribal
Development Office, Thodupuzha. A list of tribal healers/ elderly persons who have rich knowledge in medicinal plants was prepared with the support of hamlet headman (oorumooppan) and a total of one hundred and twenty respondents were selected purposively.

\section{Method of Data Collection}

Taking in to consideration of the scope and objective of the study, direct observation, semi structured interview and group discussion were followed for data collection. The field survey was undertaken with the help of hamlet headman and two local tribal men having through knowledge about the area.

\section{Statistical Tools used : Quantitative analysis}

\section{i. Relative Frequency of Citation (RFC)}

This index, which does not consider the variable u (use-category), is obtained by dividing the number of informants who mention the use of the species, also known as frequency of citation (FC), by the number of informants participating in the survey $(\mathrm{N})$. Using the same terminology, the numerator can be seen as the summation of the UR of all the informants interviewed for the species without considering the use-category (Tardio \& Pado-de Santayana, 2008).

$$
R F C_{s}=\frac{F C_{s}}{N}=\frac{\sum_{i=i_{1}}^{i_{N}} U R_{i}}{N}
$$

For example, Acalypha indica L. was 
reported as useful by 72 out of 120 informants; hence, RFC Acalypha indica $L$ $72 / 120=0.600$. This index theoretically varies from 0 , when nobody refers to the plant as useful, to 1 in the unlikely case that all the informants would mention the use of the species.

\section{ii) Use Value (UV)}

The use value (UV) demonstrates the relative importance of plants known locally. It was calculated using the following formula:

$$
U V=\sum \frac{U_{i}}{N}
$$

where $U_{i}$ is the number of uses mentioned by each informant for a given species and $\mathrm{N}$ is the total number of informants (Gazzaneo et al., 2005).

\section{iii) Relative Importance Index (RI)}

This index takes into account only the use-categories not the subcategories using the following formula.

$$
R I=\frac{R F C_{s(\max )}+R N U_{s(\max )}}{2}
$$

where $\mathrm{RFC}_{\mathrm{s}(\max )}$ is the relative frequency of citation over the maximum, i.e., it is obtained by dividing FCs by the maximum value in all the species of the survey $\left(\mathrm{RFC}_{\mathrm{s}(\max )}=\mathrm{FC}_{\mathrm{s}} / \mathrm{max} \mathrm{FC}\right)$ and $\mathrm{RNU}_{\mathrm{s}(\max )}$ is the relative number of usecategories over the maximum, obtained dividing the number of uses of the species $N U_{S}=\sum_{U=U i}^{U_{N C}} U R_{U}$ by the maximum value in all the species of the survey

$$
\left(R N_{s(\max )}=N U_{S} / \operatorname{Max}(N U) .\right.
$$

(Tardio and Pado-de Santayana, 2008).

\section{iv. The Fidelity Level (FL)}

The percentage of informants claiming the use of a certain plant species for the same major purpose was calculated for the most frequently reported diseases or ailments as:

$$
F L(\%)=\left(N_{p} / N\right) X 100
$$

Where, $\mathrm{Np}=$ number of informants that claim a use of a plant species to treat a particular disease; $\mathrm{N}=$ number of informants that use the plants as a medicine to treat any given disease. (Zashim Uddin, 2014)

\section{v. Informants' Consensus Factor (ICF)}

$$
I C F=N_{u r}-N_{t} / N_{u r}-1
$$

Where, Nur = number of use reports from informants for a particular plant-use category; $\mathrm{Nt}=$ number of taxa or species that are used for that plant use category for all informants (Zashim Uddin, 2014)

\section{FINDINGS AND DISCUSSION}

\section{Diversity of Ethnomedicinal Plants}

A total of 70 medicinal plants representing 33 families with 57 genera were used to treat various human ailments in the study area. Of the medicinal plants documented in the study area, $71.42 \%$ were collected from wild, $18.57 \%$ were from cultivated home garden and $10.01 \%$ from road side and wasteland. The same 
result was also reported elsewhere in Idukki, Kerala (Simon, 2011, Sudeesh, $2012 \&$ Ajesh, 2012 ). This shows that the culture of biodiversity conservation along with medicinal plants is well established

Table 1.

in this area. The analysis of plant habit in the area indicated that, herbs (40\%) dominated the domain of medicinal plants reported in the study area followed by trees (35.71\%), shrubs with $(21.42 \%)$ and climbers $(2.87 \%)$ (Table 1$)$.

Indigenous Medicinal Plants Used by Tribes of Idukki Wildlife Sanctuary

\begin{tabular}{|c|c|}
\hline $\begin{array}{l}\text { S1. } \\
\text { No. }\end{array}$ & Scientific Name \\
\hline 1. & Acacia caesia (L.)Willd. \\
\hline 2. & Acacia catechu (L.) Willd., Oliv. \\
\hline 3. & $\begin{array}{l}\text { Acacia nilotica (L.) Willd. } \\
\text { ex Delile }\end{array}$ \\
\hline 4. & Acalypha indica $L$. \\
\hline 5. & Acorus calamus $L$ \\
\hline 6. & Achyranthes aspera \\
\hline 7. & Adenanthera pavonina $L$. \\
\hline 8. & $\begin{array}{l}\text { Adhatoda beddomei C.B. } \\
\text { Clarke }\end{array}$ \\
\hline 9. & Adhatoda vasica Nees \\
\hline 10. & Aegle marmelos (L.) Corrêa \\
\hline 11. & Aerva lanata \\
\hline 12. & $\begin{array}{l}\text { Aganosma dichotoma (Roth) K. } \\
\text { Schum. }\end{array}$ \\
\hline 13. & $\begin{array}{l}\text { Alangium salviifolium (L.f.) } \\
\text { Wangerin }\end{array}$ \\
\hline 14. & Albizia lebbeck (L.) Benth. \\
\hline 15. & Aloe vera (L.) Burm.f. \\
\hline 16. & $\begin{array}{l}\text { Alstonia scholaris (Lin) } R \\
\text { (Brown) }\end{array}$ \\
\hline 17. & Amaranthus spinosus $L$. \\
\hline 18. & $\begin{array}{l}\text { Andrographis paniculata } \\
\text { (Burm.f.) Wall. ex Nees }\end{array}$ \\
\hline 19. & Artocarpus heterophyllus Lam. \\
\hline
\end{tabular}

\begin{tabular}{|c|c|}
\hline $\begin{array}{l}\text { S1. } \\
\text { No. }\end{array}$ & Scientific Name \\
\hline 20. & Azadirachta indica A.Juss., \\
\hline 21. & Azima tetracantha Lam. \\
\hline 22. & Bacopa monniera (L.) Pennel \\
\hline 23. & Bambusa bumbos \\
\hline 24. & Bauhinia malabarica Roxb. \\
\hline 25. & Bauhinia purpurea \\
\hline 26. & Biophytum sensitivum \\
\hline 27. & Boerhavia diffusa L. nom. cons. \\
\hline 28. & Borassus flabellifer $L$. \\
\hline 29. & Bridelia retusa (L.) A.Juss. \\
\hline 30. & $\begin{array}{l}\text { Butea monosperma } \\
\text { (Lam.) Taub. }\end{array}$ \\
\hline 31. & $\begin{array}{l}\text { Caesalpinia coriaria } \\
\text { (Jacq.) Willd. }\end{array}$ \\
\hline 32. & Caesalpinia crista \\
\hline 33. & $\begin{array}{l}\text { Caesalpinia pulcherrima } \\
\text { (L.) Sw. }\end{array}$ \\
\hline 34. & Caesalpinia sappan \\
\hline 35. & $\begin{array}{l}\text { Calotropis gigantea } \\
\text { (L.) W.T.Aiton }\end{array}$ \\
\hline 36. & $\begin{array}{l}\text { Calotropis procera } \\
\text { (Aiton) W.T.Aiton }\end{array}$ \\
\hline 37. & Camellia sinensis (L.) Kuntze \\
\hline 38. & Capsicum annuum $L$. \\
\hline 39. & Carum carvi L.m \\
\hline 40. & Carica papaya $L$. \\
\hline
\end{tabular}




\begin{tabular}{|c|l|}
\hline $\begin{array}{c}\text { S1. } \\
\text { No. }\end{array}$ & \multicolumn{1}{|c|}{ Scientific Name } \\
\hline 41. & Carthamus tinctorius \\
\hline 42. & Cassia tora/ obtucifolia \\
\hline 43. & Datura fastuosa \\
\hline 44. & Datura metel L. \\
\hline 45. & $\begin{array}{l}\text { Emilia sonchifolia } \\
\text { (L.) DC. Ex Wight }\end{array}$ \\
\hline 46. & $\begin{array}{l}\text { Eupatorium adenophorum } \\
\text { Spreng }\end{array}$ \\
\hline 47. & Euphorbia antiquorum L. \\
\hline 48. & Euphorbia hirta \\
\hline 49. & Ficus hispida \\
\hline 50. & Ficus religiosa \\
\hline 51. & Gliricidia sepium \\
\hline 52. & Hyptis suaveolens (L.) Poit. \\
\hline 53. & Ixora coccinea L. \\
\hline 54. & Jasminum angustifolium \\
\hline 55. & Jasminum grandiflorum L. \\
\hline 56. & Jatropha curcas L \\
\hline 57. & Lantana camara var. aculeate L. \\
\hline 58. & Lawsonia inermis $L$ \\
\hline 59. & Leucas aspera \\
\hline 60. & Melia azedarach L. \\
\hline 61. & Mesua ferrea \\
\hline 62. & Monochoria hastifolia C.Presl \\
\hline 63. & Ocimum basilicum L. \\
\hline 64. & Ocimum sanctum \\
\hline 65. & Persicaria chinensis \\
\hline 66. & Sida acuta Burm.f. \\
\hline 67. & Sphaeranthus indicus Linn. \\
\hline 68. & Tragia involucrate L. \\
\hline 69. & Vernonia cinerea Less. \\
\hline 70. & Woodfordia fruticosa (L.) Kurz \\
\hline
\end{tabular}

\section{Quantitative Analysis}

\section{i. Relative Frequency of Citation (RFC)}

Soap bark tree (Acacia caesia (L.) Willd) had the highest RFC (0.925) with rank I in study followed by biophytum (Biophytum sensitivum) (0.775) and hog weed (Boerhavia diffusa L. nom. cons.) (0.766) with rank II and III (See Table 1). This means that this species has been mentioned by maximum of informants and is the most recognized plant in the region having the most diverse use.

\section{ii. Use Value (UV)}

The most commonly used species was malabar nut (Adhatoda beddomei C.B. Clarke) with 82 use reports by 85 informants, giving the highest use value of 0.683. It is attributed to its use in the treatment of various diseases and it is well recognized by maximum of informants to cure asthma, wound, bleeding, blood heat, piles, cough, stomach pain and phlegm. Hog weed (Boerhavia diffusa $L$. nom. cons.) with 80 use reports by 92 informants scored second highest use value of 0.666 followed by broom weed (Sida acuta Burm.f.) with 76 use reports by 87 informants with use value of 0.633 , bael (Aegle marmelos (L.) CorrêaC.B.) with 75 use reports by 77 informants with use value of 0.625 and holly basil (Ocimum sanctum) with 74 use reports by 85 informants with use value of 0.616 . It reveals that the informants were found to have high rate of dispersal of knowledge about ethnomedicinal plants and their use. 


\section{iii. Relative Importance Index (RI)}

The plants with the maximum number of medicinal purposes (four) were found to be soap bark tree (Acacia caesia (L.)Willd) followed by neem tree (Azadirachta indica A.Juss,) (three). Thee high relative importance index of soap bark tree (Acacia caesia (L.)Willd) with RI of 0.833 reported might be an indication of its high availability and affordability in the study area.

\section{iv. The Fidelity Level (FL)}

To determine culturally important medicinal species in the society, Fidelity Level (FL) of plants has been calculated based on use reports which have been cited by ten or more informants for being used against a given ailment. The highest FL value was found in soap bark tree (Acacia caesia (L.)Willd.) with 92.50\% followed by biophytum (Biophytum sensitivum) with $77.50 \%$ and hog weed (Boerhavia diffusa L. nom. cons.) with $76.60 \%$ respectively. While selecting the most preferred plant species for each ailment category, the high Fidelity Level $(\%)$ in each category of ailment could be used.

\section{v. Informants' Consensus Factor (ICF)}

The Informant's Consensus

Table 2.

Informants' Consensus Factor (ICF) for Ailment Categories

\begin{tabular}{|c|c|c|c|c|}
\hline $\begin{array}{l}\text { S1. } \\
\text { No. }\end{array}$ & Ailment categories & $\begin{array}{c}\text { Number } \\
\text { of use } \\
\text { reports }\left(\mathbf{N}_{u r}\right)\end{array}$ & $\begin{array}{c}\text { Number } \\
\text { of taxa } \\
\left(N_{t}\right)\end{array}$ & $\begin{array}{c}\text { Informant } \\
\text { consensus factor } \\
\text { (ICF) }\end{array}$ \\
\hline 1. & Urological ailments (UA) & 205 & 9 & 0.9607 \\
\hline 2. & $\begin{array}{l}\text { Ear, nose, throat ailments } \\
\text { (ENTA) }\end{array}$ & 45 & 4 & 0.9318 \\
\hline 3. & General Health Ailments (GHA) & 594 & 30 & 0.9510 \\
\hline 4. & Eye ailment (EA) & 60 & 5 & 0.9322 \\
\hline 5. & $\begin{array}{l}\text { Gynaecological/ andrological } \\
\text { ailments (GAA) }\end{array}$ & 181 & 9 & 0.9555 \\
\hline 6. & Fever ailment (FA) & 142 & 8 & 0.9503 \\
\hline 7. & Dermatological ailment (DA) & 446 & 23 & 0.9505 \\
\hline 8. & Respiratory ailment (RA) & 167 & 11 & 0.9397 \\
\hline 9. & Gastro-intestinal ailment (GIA) & 298 & 18 & 0.9427 \\
\hline 10. & $\begin{array}{l}\text { Skeleto- Muscular ailments } \\
\text { (SMA) }\end{array}$ & 95 & 7 & 0.9361 \\
\hline 11. & Poisonous bites ailments (PBA) & 137 & 8 & 0.9485 \\
\hline 12. & Lifestyle ailments (LSA) & 312 & 20 & 0.9389 \\
\hline & Total & 2682 & 152 & \\
\hline
\end{tabular}


Factor (ICF) of 12 ailments has been represented in Table 2. The urological ailments (UA) were reported to have highest ICF value of 0.9607 followed by gynecological ailments (GAA) with ICF of 0.955, Dermatological ailments (DA) with ICF of 0.950 respectively (Table 2). High ICF value can be used to select interesting species in search of bio active compounds.

\section{CONCLUSION}

Findings of the study had indicated that, the study area is rich in knowledge on traditional medicines and their uses which were blended with the culture of local people. Fabaceae was the most used plant family for the treatment of various ailments in the area. Herbs stood first in the plant use for medicinal purpose. Most of the plants were collected from the wild environment and from medicinal gardens.

This indicates that the culture of the people had focused on biodiversity conservation. Various quantitative analyses show that this indigenous knowledge is valuable for the communities and the future generation as a scientific consideration. The study also indicates that the knowledge on indigenous medicinal plants collected and analysed would contribute to a great potential of research and discovery of new drugs to cure various ailments. The professionals involved in Animal husbandry extension have a major role to play in this regard.

\section{REFERENCES}

Ajesh, T.P, Naseef, S.A.A, \& Kumuthakalavalli, R. (2012). Ethnobotanical documentation of wild edible fruits used by Muthuvan tribes of Idukki, Kerala- India. International Journal of Pharma and Bio Sciences, 3(3): $479-487$.

Cordell, G.A. (2000). Biodiversity and drugs discovery - a symbiotic relationship. Phytochemistry, 55: 463468.

Gazzaneo, L.R.S., Lucena, R.F.P. \& Albuquerque, U.P. (2005). Knowledge and use of medicinal plants by local specialists in a region of Atlantic Forest in the state of Pernambuco. Journal of Ethnobiology \& Ethnomedicine. 1-9.

Pushpangadan, P., Rajasekharan, S. \& George, V. (2002). Indigenous Knowledge and benefit sharing. A TBGRI experiment in IK strategies for Kerala. NSE Publication, Thiruvananthapuram.

Runyoro, D.K.B., Ngassapa, O.D., Matee M.I.N., Joseph, C.C. \& Moshi, M.J. (2006). Medicinal plants used by Tanzanian traditional healers in the management of Candida infections. Journal of Ethnopharmacology,106, $158-165$.

Simon, S.M., Norman, T.S.J., Suresh, K. \& Ramachandran, V. (2011). Ethnomedicinal plants used by the Urali tribes of Idukki District, Kerala 
which are hitherto un reported in codified Ayurveda system of medicine. International Journal of Research in Ayurveda and Pharmacy, 2(2) 469472.

Sudeesh, S. ( 2012). Ethnomedicinal plants used by Malayaraya tribes of Vannapuram village in Idukki, Kerala, India. Indian Journal of Science and Technology. 1(1):7-11

Tardio, J. \& Pardo-de Santayana, M. (2008). Cultural importance indices: a comparativeanalysis based on the useful wild plants of southern
Cantabria (Northern Spain). Economic Botany. 62, 24-39.

Thirumalai, T., Kelumalai, E., Senthilkumar, B. \& David, E. (2009). Ethnobotanical study of medicinal plants used by the local people in Vellore District, Tamilnadu, India. Ethnobotanical leaflets 13, 1302-1311.

Zashim Uddin. M. \& Abul Hassan, M. D. (2014). Determination of informant consensus factor of ethnomedicinal plants used in Kalenga forest, Bangladesh. Journal of Plant Taxonomy. 21(1): 83-91, 2014 